Also it is noted, that cultural and axiological approaches also play an important role in the process of studying law definitions.

In conclusion it is summed up that the system of proposed methodological approaches to the study of law definitions provides an opportunity to focus an attention not only on their external parameters, expressed in the corresponding formal features of certain concepts, the content of which reveals the definition, but also to comprehend their deep value-semantic context, within which the spiritual foundations of being and the rational-empirical component of their particular sociocultural manifestation are combined.

Key words: methodology, methodological approach, method, law definitions, law, value, concept.

DOI: 10.33.66.3/2524-017X-2019-10-341-348

УДК 340.1

Тетяна Олексіӥвна Чепульченко, кандидат юридичних наук, завідувач кафедри публічного права факультету сочіології і права ННТУ «КПІ» ім. Ігоря Сікорського

\title{
ПРАВА ЛЮДИНИ ЯК МЕТА І МЕЖІ ПРАВОТВОРЧОСТІ
}

Постановка проблеми. Безсистемність, якою іноді характеризується правотворча діяльність, пов'язується з відсутністю чіткого уявлення про правову урегульованість тих чи інших суспільних відносин. На заваді ефективного регулювання суспільних відносин стоять чимало факторів, серед яких правові колізії і прогалини, невідповідність нормативно-правових приписів реальним потребам і очікуванням громадян і т. і. Для подолання вказаного необхідним $є$ постійне вивчення динамічного законодавства, контроль за цими змінами та відповідністю їх реальним умовам життя суспільства, особливо правам та свободам людини.

Для досягнення мети правотворчості необхідно виявити потребу в правовому регулюванні, вивчити фактори, які визначають його напрямок та які вказують на загальні очікування учасників суспільних відносин.

Зокрема, слід звернути увагу на відсутність чітких уявлень про стан усього законодавчого масиву, формально діючого в Україні. При цьому слід враховувати, що йдеться не тільки про існування чи відсутність закону з того чи іншого питання, а передусім про його відповідність сьогоднішнім умовам та поставленій меті, яка має принести соціально корисний результат, а також слугувати якісному забезпеченню та захисту основних прав людини. Адже відповідно до положень ст. 3 Конституції України: «Людина, іiі життя і здоров’я, честь і гідність, недоторканність і безпека визнаються в Україні найвищою соціальною цінністю. Права і свободи людини та їх гарантії визначають зміст і спрямованість діяльності держави. Держава відповідає перед людиною за свою діяльність. Утвердження і забезпечення прав і свобод людини $є$ основним обов'язком держави».

У зв'язку з цим особливо слід наголосити на необхідності врахування наукового обгрунтування термінів та категорій, які застосовуються суб'єктами правотворчості. Практика показує, що не завжди стрімкі правотворчі процеси у державі зважають на принцип науковості та інші важливі принципи, що породжує неоднозначне розуміння правових приписів і, відповідно, порушення основоположних прав і свобод.

Аналіз останніх досліджень та публікацій. Про потребу досліджень у цій сфері вже неодноразово наголошували такі українські фахівці в галузі теорії держави і права, як А Заєць, О. Зайчук, М. Козюбра, А. Колодій, М. Цвік, Ю. Оборотов, Н. Оніщенко, М. Погребняк, П. Рабінович, В. Селіванов, О. Скакун, О. Скрипнюк, С. Шевчук та ін.

Зокрема, значна увага приділена вивченню соціальних аспектів правотворення, його принципам та видам, нормотворчій діяльності та проблемам систематизації законодавства, етичній культурі юристів тощо такими правознавцями, як М. Баймуратов, С. Бобровник, Ж. Дзейко, Н. Железняк, 
А. Колодій, А. Малько, Г. Мурашин, Н. Оніщенко, П. Рабінович, О. Скакун, Ю. Тихомиров, В. Шаповал, Ю. Шемшученко, С. Шевчук, В. Ющика та ін. Поза тим, з огляду на згадані вище недоліки правотворчої роботи, актуальним та недостатньо вивченим залишається питання основної мети, так би мовити, центрального об'єкта такої діяльності, та відповідних меж, які будуть непорушними і які вказуватимуть на основоположні цінності у праві і державі.

Мета статті. Виходячи із актуальності обраної теми та недостатнього ії вивчення, метою статті вбачаємо загальну характеристику правотворчості та обгрунтування прав людини як основної іiї мети, а також як меж, які вказуватимуть на їі непорушність i, відповідно, слугуватимуть гарантією захисту основних прав і свобод людини.

Основні результати дослідження. У вітчизняній юридичній літературі під метою правотворчості розуміють як діалектичну взаємодію цілі (створення якісного законодавства) та результату (ефективна реалізація права) правотворчого процесу $[12$, с. 8]. При цьому стосунки всередині громадянського суспільства мають формуватися на основі усвідомлення невід'ємності і неспростовності природних прав людини. На них має спиратися позитивне законодавство держави. Вони є запорукою ефективності усієї системи соціальних відносин, що існують у суспільстві та мають відповідний механізм свого забезпечення у правовій державі. 3 огляду на вказане академік Н. Оніщенко пише, що правова система соціальної, правової держави покликана: 1) забезпечити встановлену соціальною політикою стабільність громадянської згоди шляхом проголошення, реалізації й охорони соціально-правових умов для стимулювання активної частини населення на продуктивну працю як основу особистого добробуту; 2) підтримання оптимального співвідношення між прибутками працездатної частини суспільства та непрацездатними громадянами; 3) надання адресної соціальної підтримки; 4) скорочення та обмеження масштабів зубожіння; 5) стримування безробіття; 6) забезпечення прожиткового мінімуму громадян [8, с. 8-9].

Як справедливо підкреслюється в юридичній літературі, «права людини - це мінімум загальносоціальних, загальнолюдських та загальнодемократичних вимог до правового та соціального становища кожної особи, реалізація яких повинна й може бути забезпечена в будь-якому суспільстві, незалежно від особливостей його соціально-правової системи» [1, с. 173].

Категорія прав людини діє виключно у стосунках між людиною і владою. Права людини це межі влади. Вони визначають ту сферу життєдіяльності людини, в яку влада (держава) не може втручатись і ті обов'язки, які має держава щодо людини. Стосунки між людиною і владою передбачають особливий характер: «... Концепція прав людини грунтується на трьох положеннях: по-перше, кожна влада обмежена; по-друге, кожна людина має свій автономний світ, втручатися в який не може жодна сила; по-третє, кожна людина, захищаючи свої права, може висунути претензії до держави» [10].

Українське громадянське суспільство повинно отримати можливість розвиватися незалежно від державних процесів, спираючись на власний потенціал. Людина, як його складова, має усвідомити себе як мету й найвищу соціальну цінність. У даному контексті зростає роль держави і громадянського суспільства щодо забезпечення прав людини, ії честі, гідності та природного суверенітету.

Побудова правової держави в Україні перебуває на початковому етапі, іiі становлення потребує виконання певних завдань у сфері прав і свобод людини. Основними такими завданнями, зокрема, є: а) створення системи механізмів та процедур, що гарантують суб'єктивні права на основі об'єктивного, заснованого на праві порядку державної діяльності; б) створення такого механізму взаємодії держави і влади, за якого людина є рівноправним партнером держави; в) встановлення відповідальності посадових осіб за неефективне гарантування прав людини; г) підвищення ролі держави як засобу забезпечення загальносоціальних функцій у суспільстві; д) підвищення ролі судових органів та Конституційного Суду тощо [16, с. 112].

Як одне з найважливіших завдань, пов'язаних з формуванням правової держави, слід розглядати розвиток і вдосконалення законодавства, формування, по суті, нової правової системи. Останнім часом прийнято чимало законодавчих актів, що створюють основи для подальшого розвитку нашої держави як демократичної, правової. В Конституції України одержали закріплення найважливіші принципи конституційного ладу України. Зроблено кроки у бік панування права і поділу влади, гарантування природних прав людини [9, с. 18].

Щодо природних прав людини, то гарантією їх захисту $є$ чітке визначення їх змісту та обсягу, що слугує відповідною правовою межею. У цьому контексті О. Львова підкреслює, що межі 
захищають внутрішній, природний порядок речей та їх призначення від зовнішнього втручання речей іншого роду. Межа (або рубіж) будь-якого явища покликана захистити від неприродності його функцій та призначення, відділити добро від зла, мораль від аморальності тощо [6, с. 33]. Тобто, якщо метою правотворчості є гарантування та захист основних прав людини, то моральність і природність $є$ якісними характеристиками таких меж у правотворчій діяльності державних органів, що, зокрема, $є$ складовою змісту принципу верховенства права.

Правова держава характеризується якістю власне закону, який має бути справедливим, гуманним, закріплювати невід'ємні природні права кожної людини: право на життя, на свободу, на особисту недоторканість. В даному контексті наголошується, що свобода не $є$ абсолютною. Вона допускає обмеження, тобто має певну міру. Ця міра повинна бути рівною для всіх. У правах людини виражаються можливості ії дій у різних сферах: економічній, політичній, культурній, особистій. Отже, держава визнає автономію особи щодо себе, захищає, охороняє від свавілля права людини, які стають ядром усієї правової системи. Закони та інші нормативні акти, які видає держава, узгоджуються з правами людини, підпорядковані принципу їх непорушності [14].

Суттєве значення у даному випадку мають і фактори духовної культури. Р. Давид з цього приводу підкреслював: «Норми права можуть змінюватися розчерком пера законодавця. Але в них чимало таких елементів, які не можуть бути свавільно змінені, оскільки вони тісно пов'язані з нашою цивілізацією і нашим напрямом думок. Законодавець не може впливати на ці елементи, так само, як на нашу мову і манеру міркувати» [3, с. 39].

I. Лихолат пише, що законодавець виступає лише «посередником» між суспільною необхідністю та її актуалізацією в текстах нормативно-правових актів. Таким чином, законодавець під впливом дії певних соціальних факторів розробляє (обирає, визначає) модельний варіант правотворчого порядку розв'язання проблем, що мають характер суспільної необхідності [4, с. 116-117].

Як відомо, не будь-яка поставлена законодавцем мета виявлялася реалізованою у повному обсязі. Практично завжди отримані результати виявлялися менш значимими, ніж вони прогнозуються правотворчим органом. Більше того, відмінним може бути й ступінь прояву юридичної та соціальної ефективності одних і тих самих правових норм. Можливими є ситуації, коли юридична ефективність правових норм може бути на висоті, у той час, як соціальна ефективність досить низькою [7, с. 117-118].

Правильно організована правотворча діяльність повинна забезпечити прийняття правових норм, що справляють ефективний вплив на суспільні відносини. В літературі це питання найчастіше розглядають в рамках проблеми якості законів, яку часто співвідносять з їх ефективністю.

У науковій літературі основні риси ефективності юридичних норм, як правило, зводиться до такого: по-перше, вимір ефективності пов'язаний з встановленням того, наскільки юридичні норми забезпечують здійснення цілей, поставлених владою. Ефективність є співвідношення між фактично досягнутим результатом і тією метою, для досягнення якої було прийнято відповідні правові норми; по-друге, основним мірилом ефективності правової норми $є$ та мета, заради якої створювалася норма [11, с. 12-13].

Досягнення поставленої мети в процесі правотворчості сприятиме відповідним позитивним змінам у суспільному житті.

Відповідні зміни в правовій системі демократичного суспільства полягають у тому, що право: пов'язує і обмежує державну владу (правова держава); дедалі більше набуває підстав у природному праві, в невід’ємних правах і свободах людини; набуває удосконаленого, «відпрацьованого» у законах та інших нормативно-правових актах змісту; стає неподільним, єдиним, незалежним і сильним правосуддям [13, с. 57]. У даному випадку можна говорити про створення правового закону.

Закон буде правовим, якщо законодавець - представницький орган держави - адекватно відобразить волю народу. В іншому випадку закон, у тому числі і приписи Основного Закону - Конституції, не є правовими і потребуватимуть відповідних змін. Цій вимозі відповідає ч. 3 ст. 22 Конституції України, де встановлена пряма заборона антиправового закону [5, с. 80-81].

В. Сальникова з правовим законом пов'язує питання поваги до права, у зв'язку з чим наголошує, що у сфері правотворчості поважливе ставлення до права воно знаходить вираз в узгодженні тих, що розробляються, правових норм, з реальними умовами життя суспільства [15, с. 215]. М. Гнатюк доходить висновку про те, що шанобливе ставлення до права є невід'ємним елементом правової культури посадових осіб і передбачає, зокрема, відношення до прав і свобод людини як до певних 
ціннісних орієнтирів, що визначають значення і зміст їх діяльності [2, с. 174]. Отже, втілюється в життя нова концепція взаємовідносин української держави і особи з пріоритетом останньої.

Розуміння іï прав виходить згідно з концепцією про те, що свої права людина отримує не від держави. Із цього випливають такі надзвичайно важливі положення Конституції України: про невідчужуваність і непорушність прав і свобод людини (ст. 21), про те, що конституційні права і свободи не можуть бути скасовані ( ст. 22), про їх рівність для всіх громадян (ст. 24). Це означає, що держава не може позбавити людей їх іманентних властивостей, які б мотиви вона при цьому не висувала. Щонайбільше, державі дозволяється обмежити певні права для окремих людей чи їх об'єднань і лише з метою забезпечення національної безпеки, запобігання злочинам, охорони здоров'я, захисту прав інших людей та за наявності умов, визначених Конституцією і законами. Будь-які обмеження прав за ознаками раси, кольору шкіри, політичних, релігійних та інших переконань, статі, етнічного та соціального походження, майнового стану, місця проживання, за мовними або іншими ознаками не допускаються (ст. 24 Конституції України) [17, с. 308-309].

Висновки. Отже, посадові особи правотворчих органів мають на високому рівні своєї правової культури усвідомлювати, що за кожним їх актом стоять інтереси як усього суспільства, так і конкретної людини, яка $\epsilon$ найвищою соціальною цінністю у державі. У відносинах «людина - держава», інтереси людини мають пріоритет і є межею, в яку держава не може втручатися, лише з метою захисту і гарантування прав. 3 огляду на це основна мета правотворчої діяльності держави має спрямовуватися на забезпечення невід'ємних, природних прав і свобод людини, які визначені Конституцією України та численними міжнародно-правовими договорами і які не можуть бути обмеженими чи скасованими іншими нормативно-правовими актами. Права людини, як мінімум ії соціальних благ, можуть лише удосконалюватися відповідно до реальних потреб і очікувань громадян.

\section{Список використаних джерел}

1. Бережнов А. Г. Политика и права человека // Политология. Курс лекцій / под ред. М. Н. Марченка. М. : Наука, 1993. С. 156-175.

2. Гнатюк М. Д. Правозастосування та його місце в процесі реалізації права : дис. ... канд. юрид. наук : 12.00.01. К., 2007. $211 \mathrm{c}$.

3. Давид Рене. Основные правовые системы современности. М. : Прогресс, 1988. 496 с.

4. Лихолат I. П. Раціональне та позараціональне в праві (на матеріалах законотворчості : дис. ... канд. юрид. наук : 12.00.01. К., 2001. 194 c.

5. Львова О. Л. Ціннісні орієнтації у праві як фактор утвердження принципу верховенства права // Правова держава. Вип. 18. 2006. С. 80-81.

6. Львова О. Л. Межі толерантності українських законів: аналітико-правовий зріз // Держава і право. 2018. Вип. 18. С. 23-36.

7. Общая теория государства и права : академический курс : в 3-х т. / отв. ред. М. Н. Марченко. [3-е изд., перераб. и доп.]. М. : Норма, 2007. Том 3 : Государство, право, общество. 2007. 712 с.

8. Оніщенко Н. М. Теорія прав людини в контексті соціокультурного змісту Конституції України 1996 року // Сьомі юридичні читання: Матеріали Міжнародної наукової конференції 19-20 травня 2011 р. К. : Вид-во НПУ ім. М. П. Драгоманова, 2011. С. 6-10.

9. Оніменко Н. М. Гармонізація правової системи України: основні напрями та тенденції // Юридична газета. № 18 (78). 2006. 28 вересня. С. 18.

10. Осетинський B. Введення у концепцію прав людини // За матеріалами Вищого міжнародного курсу захисту прав людини, Гельсінська фундація прав людини (Варшава, Польща). URL: http://www.ccf.org.ua/for-socialworkers-article.

11. Перфильев В. В. Действие права (понятие, структура, свойства) : автореф. дисс. ... канд. юрид. наук : 12.00.01. М., 1975. $16 \mathrm{c}$.

12. Плавич С. В. Теоретико-методологічні засади правотворчості: дис... канд юрид. наук: 12.00.01. К., 2009. 215 с.

13. Політика, право і влада в контексті трансформаційних процесів в Україні: монографія / Кресіна I. О., Матвієнко А. С., Оніщенко Н. М. та ін.; За ред. І. О. Кресіної. К. : Ін-т держави і права ім. В.М. Корецького НАН України, 2006. 304 с.

14. Політична культура демократичного суспільства: стан і перспективи в Україні. Матеріали Всеукраїнської науково-практичної конференції, 26-27 лютого 1998 р. К. : Гнозис, 1998. 226 с.

15. Сальников В. П. Правовая культура личности как целевая установка юридического всеобуча // Актуальные проблемы юридического всеобуча в условиях формирования социалистического правового государства : Межвуз. сб-к статей / под ред. И. А. Королева. М., 1990. С. 214-220. 
16. Теорія держави і права: Академічний курс / За ред. Н. М. Оніщенко, О. В. Зайчука. К. : Юрінком Інтер, 2006. $688 \mathrm{c}$.

17. Чепульченко T. О. Категорія прав людини у площині наукового дискурсу // Альманах права. Правова аналітика: доктринальні підходи та галузеві виміри. 2018. Вип. 9. - С. 305-310.

\section{References}

1. Berezhnov A. H. Polytyka y prava cheloveka // Polytolohyia. Kurs lektsii / pod red. M. N. Marchenka. M. : Nauka, 1993. S. 156-175.

2. Hnatiuk M. D. Pravozastosuvannia ta yoho mistse v protsesi realizatsii prava : dys. ... kand. yuryd. nauk : 12.00 .01 . K., 2007. $211 \mathrm{~s}$.

3. Davyd Rene. Osnovnыe pravovыe systemы sovremennosty. M. : Prohress, 1988. 496 s.

4. Lykholat I. P. Ratsionalne ta pozaratsionalne v pravi (na materialakh zakonotvorchosti : dys. ... kand. yuryd. nauk : 12.00.01. K., 2001. $194 \mathrm{~s}$.

5. Lvova O. L. Tsinnisni oriientatsii u pravi yak faktor utverdzhennia pryntsypu verkhovenstva prava // Pravova derzhava. Vyp. 18. 2006. S. 80-81.

6. Lvova O. L. Mezhi tolerantnosti ukrainskykh zakoniv: analityko-pravovyi zriz// Derzhava i pravo. 2018. Vyp. 18. S. 23-36.

7. Obshchaia teoryia hosudarstva y prava : Akademycheskyi kurs : v 3-kh t. / otv. red. M. N. Marchenko. [3-e yzd., pererab. y dop.]. M. : Norma, 2007. Tom 3 : Hosudarstvo, pravo, obshchestvo. 2007. $712 \mathrm{~s}$.

8. Onishchenko N. M. Teoriia prav liudyny v konteksti sotsiokulturnoho zmistu Konstytutsii Ukrainy 1996 roku // Somi yurydychni chytannia: Materialy Mizhnarodnoi naukovoi konferentsii 19-20 travnia $2011 \mathrm{r}$. K. : Vyd-vo NPU im. M. P. Drahomanova, 2011. S. 6-10.

9. Onishchenko N. M. Harmonizatsiia pravovoi systemy Ukrainy: osnovni napriamy ta tendentsii // Yurydychna hazeta. № 18 (78). 2006. 28 veresnia. S. 18.

10. Osetynskyi $V$. Vvedennia u kontseptsiiu prav liudyny // Za materialamy Vyshchoho Mizhnarodnoho kursu Zakhystu Prav Liudyny, Helsinska Fundatsiia Prav Liudyny (Varshava, Polshcha). URL: http://www.ccf.org.ua/for-socialworkers-article.

11. Perfylev V. V. Deistvye prava (poniatye, struktura, svoistva) : avtoref. dyss. ... kand. yuryd. nauk : 12.00.01. M., $1975.16 \mathrm{~s}$.

12. Plavych $S$. $V$. Teoretyko-metodolohichni zasady pravotvorchosti: dys... kand yuryd. nauk: 12.00.01. K., 2009. $215 \mathrm{~s}$.

13. Polityka, pravo i vlada v konteksti transformatsiinykh protsesiv v Ukraini: monohrafiia/ Kresina I. O., Matviienko A. S., Onishchenko N. M. ta in.; Za red. I. O. Kresinoi. K. : In-t derzhavy i prava im. V.M. Koretskoho NAN Ukrainy, 2006. $304 \mathrm{~s}$.

14. Politychna kultura demokratychnoho suspilstva: stan i perspektyvy v Ukraini. Materialy Vseukrainskoi naukovopraktychnoi konferentsii, 26-27 liutoho 1998 r. K. : Hnozys,1998. 226 s.

15. Salnykov V. P. Pravovaia kultura lychnosty kak tselevaia ustanovka yury $\neg$ dycheskoho vseobucha // Aktualnыe problemы yurydycheskoho vseobucha $\mathrm{v}$ uslovyiakh formyrovanyia sotsyalystycheskoho pravovoho hosudarstva : Mezhvuz. sb-k statei / pod red. Y. A. Koroleva. M., 1990. S. 214-220.

16. Teoriia derzhavy i prava: Akademichnyi kurs / Za red. N. M. Onishchenko, O. V. Zaichuka. K. : Yurinkom Inter, 2006. $688 \mathrm{~s}$.

17. Chepulchenko T. O. Katehoriia prav liudyny u ploshchyni naukovoho dyskursu // Almanakh prava. Pravova analityka: doktrynalni pidkhody ta haluzevi vymiry. 2018. Vyp. 9. - S. 305-310.

\section{Чепульченко Т. О. Права людини як мета та межі правотворчості}

У статті підкреслюється, що регулюванню відносин у суспільстві перешкоджають чимало факторів, таких, як колізії і прогалини у праві, невідповідність нормативно-правових приписів реальним потребам і очікуванням громадян тощо. Для подолання вказаного необхідним є постійне вивчення динамічного законодавства, контроль за цими змінами та відповідністю їх реальним умовам життя суспільства, особливо, правам та свободам людини.

Звертається увага на відсутності чітких уявлень про стан усього законодавчого масиву, формально діючого в Україні. Мова йде не тільки про існування чи відсутність закону з певного питання, а передусім про його відповідність сьогоднішнім умовам та поставленій меті, яка має принести соціально корисний результат, а також слугувати якісному забезпеченню та захисту основних прав людини. У зв'язку з цим наголошується на необхідності врахування наукового обгрунтування термінів та категорій, які застосовуються суб'єктами правотворчості.

Підкреслюється, що права людини - це мінімум загальносоціальних, загальнолюдських та загальнодемократичних вимог до правового та соціального становища кожної особи. Категорія прав людини діє виключно у стосунках між людиною і владою. Права людини - це межі влади. Вони визначають ту сферу життєдіяльності людини, в яку державна влада не може втручатись, і ті обов'язки, які має держава щодо людини. У даному контексті автор 
згадує межі природності і моральності, які роблять закон правовим. А закон буде правовим, якщо законодавець адекватно відобразить волю народу.

Ключові слова: влада, держава, закон, права людини, правотворчість.

\section{Chepulchenko T. A. Human rights as the goal and limits of law-making}

The article emphasizes that the regulation of relations in the society is hampered by many factors, such as conflicts and gaps in law, inconsistency of legal regulations with real needs and expectations of citizens, etc. In order to overcome the above, it is necessary to constantly study the dynamic legislation, monitor these changes and comply with their real conditions of life of the society, especially human rights and freedoms.

The main features of the effectiveness of legal norms are determined: the measurement of effectiveness is related to the establishment of how legal rules ensure the implementation of the goals set by the authorities; the main measure of the effectiveness of the legal norm is the purpose for which the norm was created.

Attention is drawn to the lack of clear ideas about the state of the entire legislative array formally operating in Ukraine. It is not only about the existence or absence of a law on a particular issue, but above all about its compliance with today's conditions and goals that should bring a socially beneficial result, as well as serve the quality of the protection and protection of fundamental human rights.

In this regard, it is emphasized on the need to take into account the scientific substantiation of the terms and categories used by actors of law-making. Practice shows that not always rapid law-making processes in the state consider scientific principles and other important principles that give rise to ambiguous understanding of legal requirements and, accordingly, lead to a violation of basic human rights.

In this regard, it is emphasized that the rule of law is characterized by the quality of the law, which should be fair, humane, to establish the inalienable natural rights of every person: the right to life, to freedom, to personal integrity. In this context it is noted that freedom is not absolute. It allows a limitation, that is, it has a certain degree. This measure should be equal to everyone.

It is emphasized that human rights are the minimum of general social, universal and general democratic requirements to the legal and social status of each person. The category of human rights is exclusively in the relationship between man and authority. Human rights are the limits of power. They define the sphere of human life in which state power can not interfere with those duties that the state has in relation to a person. In this context, the author mentions the limits of naturalness and morality that make the law legal. And the law will be legal if the legislator adequately reflects the will of the people.

Key words: power, state, law, human rights, law-making.

DOI: 10.33.66.3/2524-017X-2019-10-348-353 